\title{
パッシブ型 RFID タグ・センサを鉄筋コンクリート部材に埋設する場合の 通信性能評価法，および壁・スラブ部材への適用 RF COMMUNICATION PERFORMANCE EVALUATION OF HF BAND PASSIVE RF TRANSPONDER INSTALLED INSIDE REINFORCED CONCRETE WALLS AND SLABS
}

藤本郷 史*, 吉峰侑 吾**, 平原悠生 ${ }^{* *}$, 大久保孝昭****

\author{
Satoshi FUJIMOTO, Yugo YOSHIMINE, Yuki HIRAHARA \\ and Takaaki OHKUBO
}

\begin{abstract}
In order to fulfill the growing needs for effective and efficient monitoring of construction and maintenance records, many challenging proposals are found to install RF devices (i.e. IC tags and wireless sensors) inside reinforced concrete (RC) members. This paper presents RF communication performance indices for these RF systems, focusing on the influences of steel-rebar and concrete located near the RF devices and reader-writer. Experimental evaluation using the above indices has shown that RF communication performance of $\mathrm{RF}$ device installed inside $\mathrm{RC}$ members does not hold addition rule for performance degradation caused by existence of concrete and re-bars. The results have also implied a possible method to assure RF communication performance before concrete placement. Repeatability of these results is assessed by comparative measurements of magnetic field strength under various conditions; communication distance, rebar arrangement, reader-writer types and RF device types.
\end{abstract}

Keywords : Reinforced concrete member, Radio Frequency Identification, Monitoring, Construction management, Construction record, Electronics and information technology 鉄筋コンクリート部材，RFID，モニタリング，建設マネジメント，履歴情報，電子情報技術

\section{1. はじめに}

日本国内には膨大な建築物 1)・社会基盤ストック 2)が存在する。「こ れらの膨大なストックを如何に効率よく信頼性をもって更新・維持 管理・除却してゆくか」という課題は, 現状の建設分野における最 重要テーマの一つである。著者らは，このような社会的ニーズに応 える技術的な可能性を探索する立場から，電子情報技術に着目して 多面的に研究を進めている ${ }^{3), 4), 5)}$ 。

本報では，上述の電子情報技術の一つとして，RFID（Radio Frequency Identification)技術 6-10)を検討する。材料施工分野では, 鉄筋コンクリート部材 (以後, RC 部材と表記) の内部に IC タグや $\mathrm{RF}$ 通信機能を備えたセンサなど（以後, RFID タグ・センサと表記） を埋設しようとする提案が多くみられる。例えば，生コンクリート の練り混ぜ時に IC タグを投入して材料トレーサビリティを確保し ようとする案 ${ }^{11)}, \mathrm{RF}$ 通信機能付きセンサを鉄筋コンクリート部材 内の鉄筋に設置してモニタリングをおこなう案 ${ }^{12)}$ ，プレキャスト部
材へIC タグを埋設する案 13),14)などである。このような研究動向を 背景として，本報は鉄筋コンクリート部材内に RFID タグ・センサ を埋設する場合の要素技術的な可用性を検討する。

RFID のような新技術の導入にあたっては，様々な社会的・技術 的ハードルを予め把握しておくことが必要である。建設産業の規模 や鉄筋コンクリート部材に使用されるコンクリート材料や配筋方法, 要求される性能等の多様性を考えると, どの設計因子がどの性能に 影響を与えるのかを可能な限り定量的に把握しておく必要がある。 なかでも，硬化コンクリートの内部に RFID タグ・センサを埋設す る場合，交換に多くの手間がかかるため， RF 通信性能の確保に関 わる評価の重要性が高い。そこで，上述の技術的ハードルのうち， $\mathrm{RC}$ 部材内部に埋設された RFID タグ・センサと $\mathrm{RC}$ 部材外に設置 されたリーダライタ（以後，RW と表記）との間の通信性能を本報 の対象とした。具体的には，以下の検討項目について報告する。

1） RC 部材に埋設した場合の通信性能評価を目的として，RF 通
本報の一部は，文献33で報告済みである。

* 広島大学大学院工学研究院 助教 $\cdot$ 博士 (工学)

**元 広島大学大学院工学研究科建築学専攻 大学院生. 修士 (工学)

*** 広島大学大学院工学研究科建築学専攻 大学院生

**** 広島大学大学院工学研究院 教授. 工博
Assist. Prof., Graduate School of Eng., Hiroshima Univ., Dr. Eng. Former Graduate Student, Graduate School of Eng., Hiroshima Univ.

Graduate Student, Graduate School of Eng., Hiroshima Univ. Prof., Graduate School of Eng., Hiroshima Univ., Dr. Eng. 
信の手順に基づいた定量的な通信性能評価指標を提示した。

2） $\mathrm{RC}$ 壁部材を模擬した各種試験体を対象に RF 通信実験を行い, 上述 1)で提示した指標の有用性を検証した。

3）鉄筋やコンクリートの存在が通信性能に及ぼす影響を定量的 に評価した。特に, 鉄筋とコンクリートが通信性能に与える影 響には加法性がないことを示した。また, RFID タグ・センサ が RC 部材内にある場合の方が，打設前の配筋のみ行った状態 の同位置よりも通信性能が高い場合があることを示した。

4）上述 3) と同一の条件における磁界強度の測定を通じて, 上述 3)の現象の要因を解明し, 再現性の検証を行った。

なお RFID には，HF 帯 $(13.56 \mathrm{MHz}, 125 \mathrm{kHz}) や \mathrm{UHF}$ 帯など複数 の周波数帯，規格がある。本報では，ISM 周波数の一つであり世界 的に法的規制が少ない点 ${ }^{15)}$, 現状の国内シェアが高い点 (R/W 出荷 金額の $\left.80 \%{ }^{16)}\right)$ などの特長を考慮して, $13.56 \mathrm{MHz}$ 帯を利用するパ ッシブ型 RFID システムを対象とした。

\section{RF 通信の手順に基づく評価指標の提案}

前述のように RFID タグ・センサを $\mathrm{RC}$ 部材に埋設しようとする 研究例は多数ある。これらの建設分野における研究例では, 通信で きる距離を指標として通信性能を評価 10),14),17)することが多い。この ような通信可能距離を指標とした評価法は簡便で直観的という利点 があるが，一方で，

1）最大距離より短い地点で通信できない場合の評価が難しい

2）通信が成功したり失敗したり寸る場合の評価が難しい といった課題が指摘できる。

RFID 分野では, 通信距離に加えて各種の解析的・実験的評価も 行われている。例えば, 理論 18)や数值解析に基づく評価 ${ }^{19)}$, 対応す る磁界強度測定 20),21)，波形測定 22 ，応答時間測定 23 ) などである。 これらのうち理論や解析に基づく手法は, 本報の想定条件のように, 不均質な媒質(ex. コンクリート)や, 十分な設置位置精度の無い導電 体(ex. 異形鉄筋, 結束線)が存在する十分に制御されていない供用環 境下を対象とする場合, 適用が難しいといわれている ${ }^{24)}$ 。また, 実 験的手法の多くは, 個別の設計要因（例えば, 磁界強度は RW アン テナからの磁界の到達, 波形測定はノイズ等の回路への影響, 応答 時間は制御装置のスループット etc.）を評価するものである。

以上のように，既往の RFID 開発分野における解析・実験的手法 は，RFID センサ・タグや RW のアンテナ，電子回路等の “設計” へのフィードバックを目的としており，RFID システム（RW とそ の制御装置, RFID タグ・センサの組み合わせ）全体としての通信 性能評価を目的としていない。また，システム全体の通信性能を反 映するものでもない。したがって，建設分野における RFID システ ムの“選定”を目的とした評価には十分でないといえる。

以上の考察をもとに，本報では， $\mathrm{RF}$ 通信の手順に基づく定量的 で簡便な通信性能評価指標を提示する。図 1 に $\mathrm{RF}$ 通信の手順を示 す。 RF 通信は複数のコマンドの往復によって実現されるが，コン クリートや鉄筋の存在や通信距離の増加によって通信が不安定にな るほど，コマンドの実行が途中で途切れる可能性が確率的に高まる 注1)。したがって, 全コマンドのうち, どこまで実行できたかを計量 することで通信性能（通信の可否や安定性）を評価することができ る。このような考え方のもとに，本報では，夕グ捕捉率（式 1）と
通信成功率（式 2）の二つの指標を提案した。

図 1 によると，タグの捕捉コマンド（REQB とその応答）の実行 が成功すれば RFID タグ・センサは発見できる注 2)。したがって,「RC 部材に埋設された RFID タグ・センサを発見できるか」という評価 の指標は式(1)で定義できる。すなわち, 測定一回あたり REQB コ マンド通信が $N_{R}$ 回成功するまで行うとする。この試行における $b_{c}$ の集合 $B_{c}$ のうち, タグの捕捉に成功した元の集合を $C_{c}=\left\{c_{c} \in B_{c} \mid b_{c}=\right.$ true $\}$ とすると,

タグ捕捉率 $R_{c}=\frac{\operatorname{card} C_{c}}{N_{R}} \times 100 \quad \%$ 式(1) 注3)

一方で図 1 によれば，RW-RFID タグ・センサ間のデータの読み 書きを安定的に行うには，全コマンドが実行される必要がある。し たがって,「RC 部材内に埋設された RFID タグ・センサ内のデータ を安定して読み書きできるか」という評価の指標は式(2)のように定 義できる。すなわち, $N_{R}$ 回における $b$ の論理積 $b_{p} \wedge b_{f} \wedge b_{k} \wedge b_{r} \wedge b_{d e}$ の集合 $B$ について，ポーリングからタグの解放までの全コマンドが 成功した元の集合を $C_{\text {all }}=\left\{c_{\text {all }} \in B \mid c_{\text {all }}=\right.$ true $\}$ とすると

$$
\text { 通信成功率 } R_{\text {all }}=\frac{\text { card } C_{\text {all }}}{N_{R}} \times 100 \quad(\%) \quad \text { 式(2) 注3) }
$$

ただし，集合 $X$ の元の個数を $\operatorname{card} X$ と表す。

なお，上述のように本報の評価法ではタグ捕捉できるまでリトラ イするので, 後述の実験結果に示寸ように, タグ捕捉率 $=100 \%$ or 0\%のどちらかとなる。

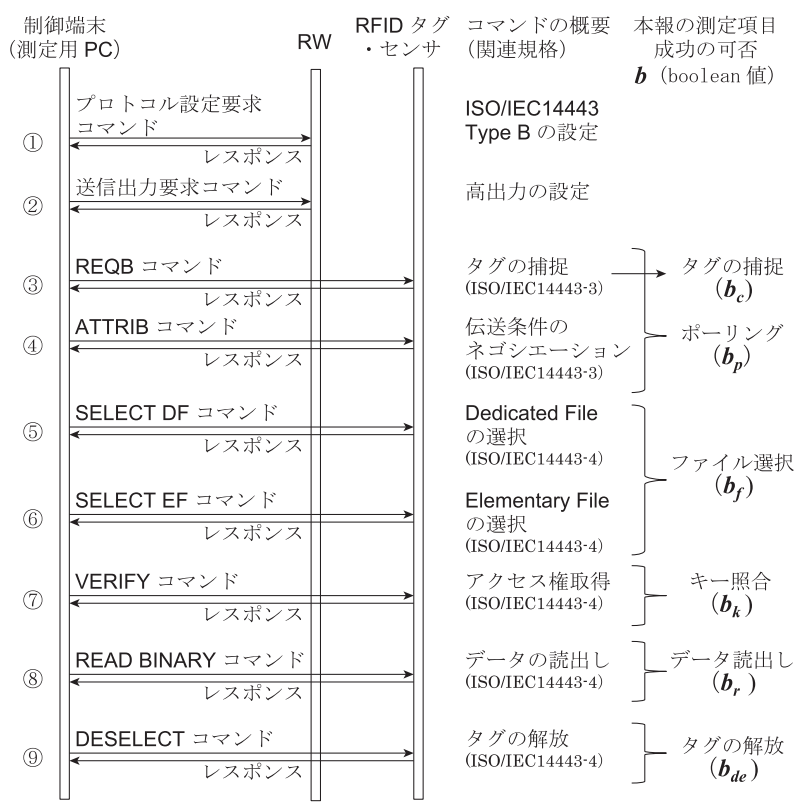

※本報では, REQB コマンドは $N_{R}=100$ (回) 成功までリトライすると設定。 成功したら次のコマンドを実行。

図 $1 \mathrm{RF}$ 通信の手順と対応する本報の測定項目 （※簡単のためデータの書き込みコマンドは省略）

\section{3. 実験の方法}

\section{1 試験体と使用材料の概要}

図 3 図 4 に試験体の概要を示す。埋設対象には $\mathrm{RC}$ 壁もしくは スラブを想定した。埋設後を想定した RC 試験体，コンクリート打 
設前を想定した鉄筋試験体，およびコンクリートのみの影響を抽出 するためにコンクリート試験体を作製して用いた。コンクリートは, 普通コンクリート $(27-18-20-\mathrm{N}, \mathrm{w} / \mathrm{c}=54 \%, \mathrm{~s} / \mathrm{a}=46.8 \%)$, 鉄筋は D10 （SD-295）を用いた。13.56MHz 帯の RF 通信性能に対するコンクリ 一ト材齢や含水率の影響は少ないとの報告 17)があるが，念のため材 齢 91 日以上経過してから測定を行った。

\section{2 測定の方法}

図 5 に測定方法の概要を示す。 $\mathrm{RW}$ が $\mathrm{RC}$ 壁の表面にほぼ接して おり注 4), RW アンテナ中心の鉛直線上に RFID タグ・センサが埋設 されている状態（埋設時としては最も通信性能が高いと予想される 条件）を想定した。すなわち， $\mathrm{S}_{1}$ 平面（図 2 図 4 参照）とアンテ ナ面が一致し, 且つ, アンテナ中心が測定線 $\mathrm{L}_{1}$ と一致するように $\mathrm{RW}$ を設置した。測定線 $\mathrm{L}_{1}$ 上で，木製の棒の先端に接着した RFID タグ・センサを $\mathrm{RW}$ から遠ざけてゆき, 各通信距離 $d_{R W}$ について通 信コマンドの成功の可否（図1のb) を測定した。

実験には，RFID タグ・センサとして IC タグを 3 種類を用いた。 また，3機種の RW を用いた。ICタグは設置向きによって通信性能 が異なる 25)が，本報では最も通信できる距離の大きい“向き”につ いて検討を行った。すなわち, 各 IC タグが空気中で最も通信距離 を長くなる “向き”を既報の方法 25) で予め測定しておき，その“向 き”が測定線 $\mathrm{L}_{1}$ と一致するように木製棒の先端に設置した。

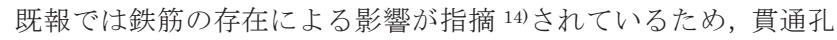
（ $\phi 48 \mathrm{~mm} ）$ は鉄筋との相対位置を考慮して, 複数設けた。これらの 比較による RFID タグ・センサの設置位置は本報の検討対象としな かった。

貫通孔自体が測定結果に影響を及ぼす可能性も考えられる。そこ で，いくつかの代表的な測定位置と通信距離（ $d_{R W}=10,30,50,70$, 100, 150,200mm）について，コンクリート棒で封入した場合（図 6 測定法 A）とコンクリート棒を用いない場合（図 6 測定法 B) を 比較して, 測定結果に大きな差が無いことを確認してある。後述 5.1 節では，コンクリートの存在によって通信性能に差が生じることを 示した。この結果は, 上述の “大差がない”という結果と一見矛盾 する。磁界を発生させているアンテナ線（直径 $20 \mathrm{~mm}$ 程度）が貫通 孔（直径 $48 \mathrm{~mm}$ ）より相当程度離れているために影響が少なかった ものと思われるが，今後，検証を重䄈る必要がある。

測定対象でない他の貫通孔については図 6 右の方法で塞いで測定 をおこなった。なお，コンクリート棒の作製には，試験体本体と同 一調合のコンクリートを用いた。本報の範囲では, データ読出しは 4byte と設定し, データ書き込みは行わなかった。これらデータ量 や読み書きの別についての影響評価も今後の検討課題とした。

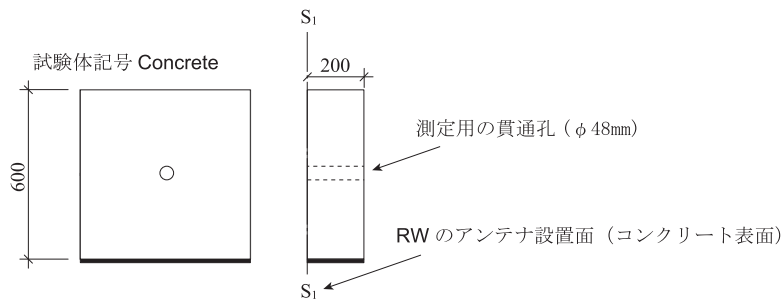

図 2 コンクリートによる影響を評価するための試験体概要 (無筋コンクリート。以後「コンクリート試験体」と呼ぶ)

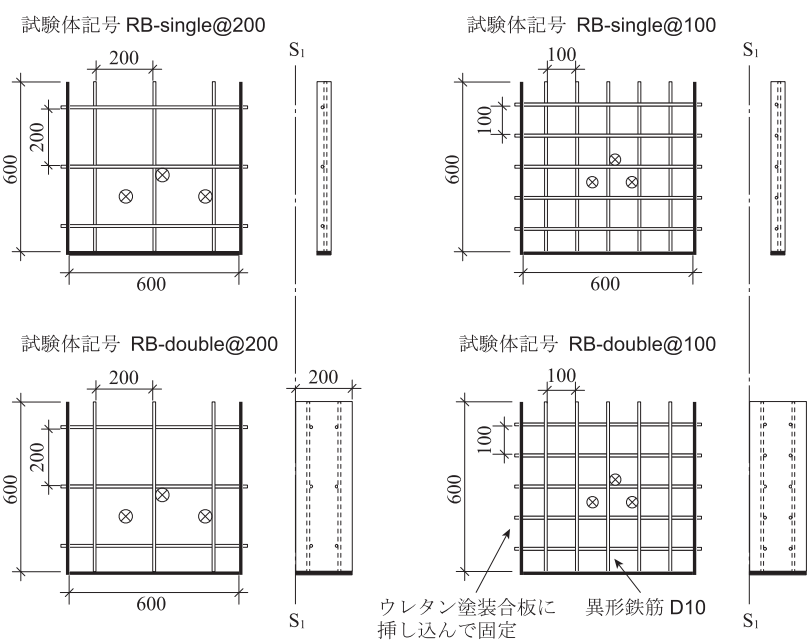

凡例 $\mathrm{S}_{1}$ : RW のアンテナ設置面（打設後のコンクリート表面を想定した位置）

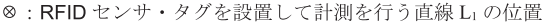
(※ RC 試験体における貫通孔と鉄筋との相対位置が同一)

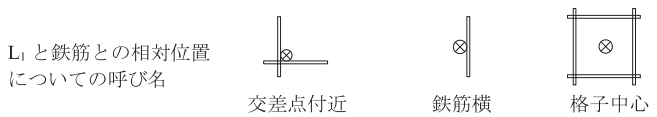

図３コンクリート打設前を想定した試験体の概要 (以後, これらを総称して「鉄筋試験体」と呼ぶ)

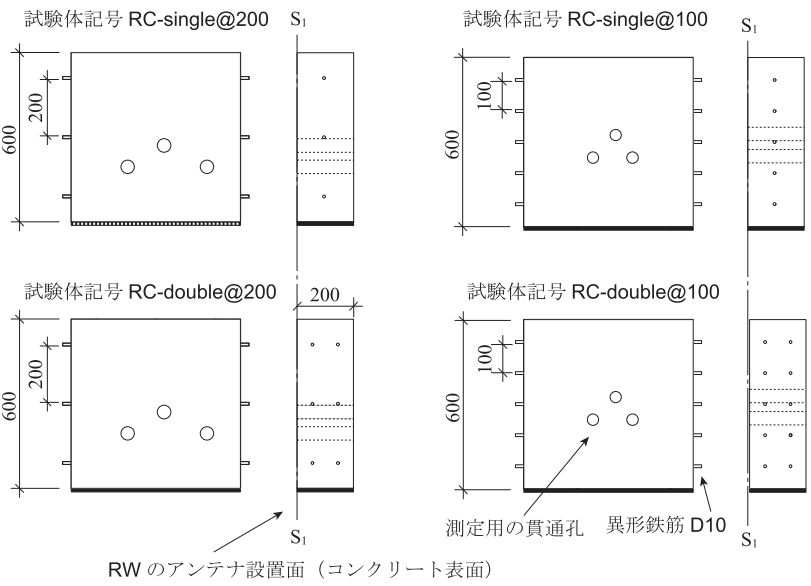

図 $4 \quad \mathrm{RC}$ 壁やスラブを想定した鉄筋コンクリート試験体の概要 (配筋は対応する鉄筋試験体と同じ。以後，「RC 試験体」と呼ぶ)

表 1 実験の因子と水準

\begin{tabular}{|c|c|c|}
\hline & 因子 & 水準（)内は試験体の記号を示す \\
\hline \multirow{3}{*}{$\begin{array}{l}\text { 試 } \\
\text { 体 }\end{array}$} & 構成材料(記号) & $\begin{array}{l}\text { 試験体を設置しない（障害物なし） } \\
\text { 鉄筋のみみ(RB), 鉄筋コンクリート(RC), } \\
\text { 無筋コンクリート(Concrete) }\end{array}$ \\
\hline & 配筋間隔(記号) & 100mm(記号@100),200mm(記号@200) \\
\hline & 配筋の種別（記号） & シングル配筋(single)，ダブル配筋(double) \\
\hline \multirow{4}{*}{ 溳 } & 通信距離 $d_{R W}(\mathrm{~mm})$ & $\begin{array}{l}\text { Omm〜タグ捕捉率 } 0 \% \text { となる範囲（※1） } \\
\text { (図 } 5 \text { 参照) }\end{array}$ \\
\hline & $\begin{array}{l}\text { 鉄筋と測定線 } \mathrm{L}_{1} \\
\text { との相対位置 }\end{array}$ & $\begin{array}{l}\text { 交差点付近, 鉄筋横, 格子中心 } \\
\text { (呼び名の内夋については図 } 3 \text { 参照) }\end{array}$ \\
\hline & RW & $\begin{array}{l}\text { RW-A, RW-B (いずれも PC 接続型) } \\
\text { RW-C (手持ち型, 磁界強度測定にのみ利用) }\end{array}$ \\
\hline & RFID タグ・センサ & $\begin{array}{l}\text { RFID-A, RFID-B,RFID-C } \\
\text { (いずれもIC タグ) }\end{array}$ \\
\hline
\end{tabular}

※1 タグ捕捉率 $0 \%$ よ遠い範囲についても適宜, 確認のための測定を実施。 


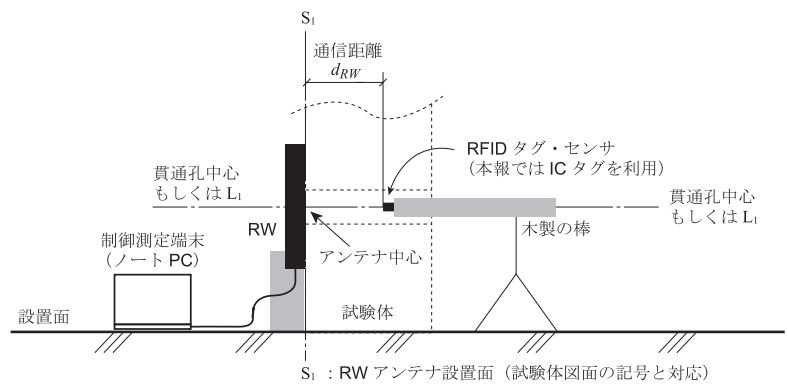

図 5 測定方法の概要
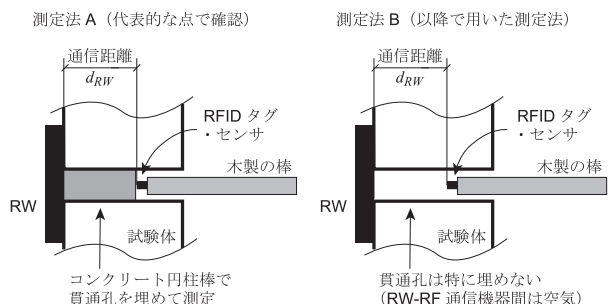

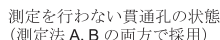
買通孔在埋めて澌定

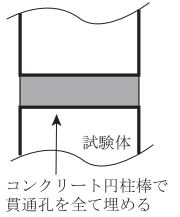

図 6 測定方法の詳細（貫通孔の影響を排除するための配慮）

\section{4. 実験結果と考察（指標の有用性）}

\section{1 タグ・センサの発見と情報読書きにおける通信性能の違い}

図 7 図 9 に代表的な水準における夕グ捕捉率 $R_{c}$ と通信成功率 $R_{\text {all }}$ の比較を示す。通信成功率が $100 \%$ を回る距離は, 全ての水準 でタグ捕捉率よりも $20 \mathrm{~mm}$ 以上小さかった。水準によっては $60 \mathrm{~mm}$ 以上異なる場合もあり, RC 工事における寸法精度を考慮に入れて も有意な差が観察された。この結果から, RFID タグ・センサを埋 設する場合, 埋設箇所を発見できても RFIDタグ・センサとの安定 的なデータ読み書きが行えない場合があると予測できる。このよう な予測は，通信距離のみでは提供できない知見であり，本報の $2 つ$ の提案指標を使い分けることの有用性を示している。

既往の提案例を概観すると, パッシブ IC タグの活用法は, a) IC タグそのものにデータを保管する, b) IC タグのユニーク ID を利用 して箇所を同定し保管情報自体はサーバに格納する, という 2 方式 に大別される ${ }^{26)}$ 。 方式であれば通信成功率 $R_{\text {all }} \fallingdotseq 100 \%$ が要求性能 となるが, $\mathrm{b}$ 方式では, タグ捕捉率 $R_{c} \fallingdotseq 100 \%$ が要求性能となる。し たがって，上述の測定結果は RFID システムの仕様によっても確保 できる通信性能が異なることを意味している。

なお, 著者らが別途行った建築現場実験では, IC タグを発見した もののデータの読書きが行えない例が少数みられた。このような現 地実験を通じて，上述の評価の妥当性についても確認した。

\section{2 タグ・センサ選定のための比較資料としての指標の有用性}

図 8 上(RFID-C) と同一の試験条件について, RFID タグ・センサ をRFID-B に変更して測定した結果を図 9 に示す。製造メーカによ ると RFID-C はRFID-Bの復調回路を改善したものである。RFID-B の場合のタグ捕捉率はおおむね RFID-C と同じ距離まで $100 \%$ あ るのに対して, 通信成功率 $R_{\text {all }}$ は通信距離 $d_{R W}$ が小さい場合から低下 しており, RFID-C とは異なる傾向を示した。この結果は, 通信成 功率の向上のための今後の技術開発において, 復調回路の改善（鉄 筋やコンクリートの存在に起因するノイズへの耐性向上）が有効で あることを示唆する。以上のように，本報で提案する評価指標は， 異なる複数の RFID タグ・センサの通信性能を相対比較するための
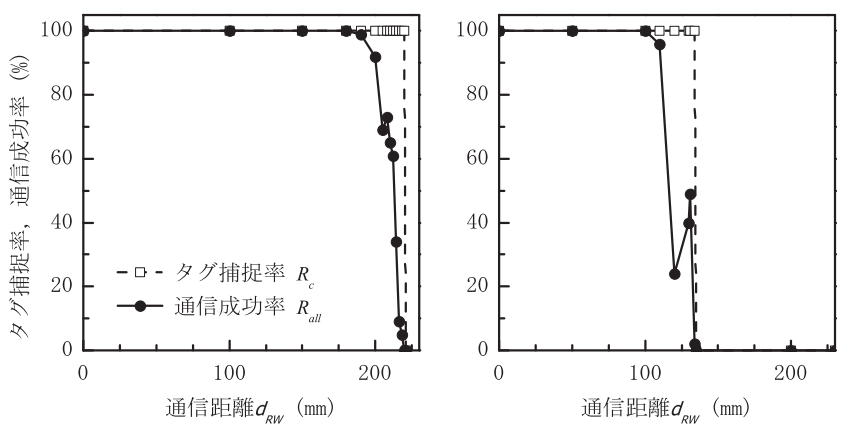

図 7 タグ捕捉率と通信成功率の比較 左 : 障害物がない場合 右：鉄筋試験体を設置した場合((RB-single@100,格子中心) 測定条件：RW-B, RFID-C（表 1参照）
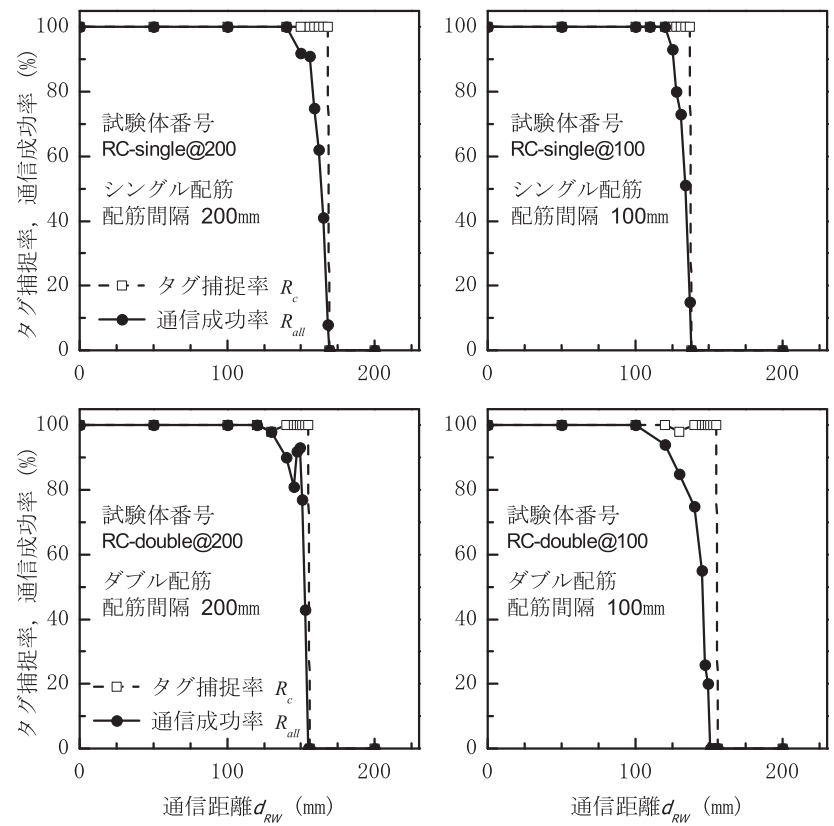

図 8 タグ捕捉率と通信成功率の比較（RC 試験体の場合） 測定条件：RW-B, RFID-C, 格子中心（表 1 参照）
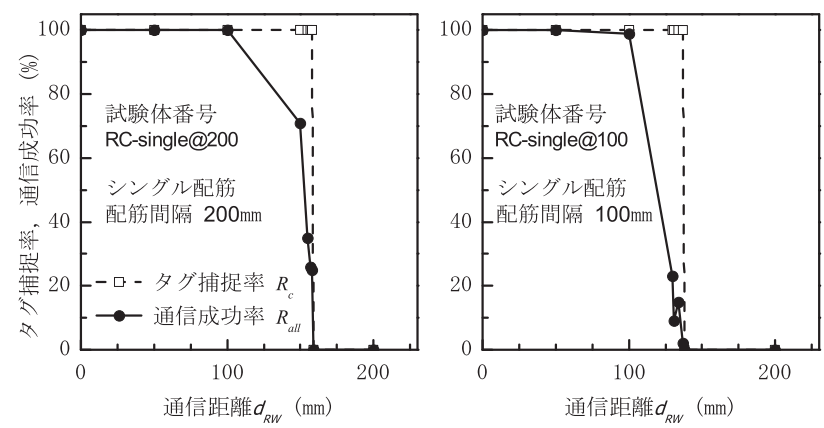

図 9 タグ捕捉率と通信成功率の比較（RC 試験体の場合） 測定条件：RW-B, RFID-B，格子中心（表 1参照）

基礎資料としても有用と考えている。

\section{3 通信の安定性評価の観点からみた評価指標の優位性}

図 10 に通信が不安定な場合のタグ捕捉率の測定結果例を示寸。RF 通信は非接触で行われるので，外部環境に影響を受けて不安定（通 信できたりできなかったり）となることがある。特に，鉄筋などの 導体やコンクリートなどの不均質な材料が障害物として存在する $\mathrm{RC}$ 部材への埋設ではその影響が大きい。このような場合，単純に 
通信できる最大距離を指標として通信性能を評価するのは適切でな い。例えば，図 10 左では $70 \mathrm{~mm}$ 付近でのみタグ捕捉率 $R_{c}=100 \%$ であった。このような場合, $70 \mathrm{~mm}$ より距離が長くても短くても通 信できない。したがって, 通信できる最大距離を指標とした評価は 適切でない。また, 図 10 右では, タグ捕捉率は $100 \%$ ではなく, 通信安定性が低い。距離だけで評価するとその時々の試験結果によ って大きく評価がばらつくことになるであろう。以上のように, RFID システム（RW とその制御装置，RFID タグ・センサの組み 合わせ）の選定にあたって通信安定性を評価するための基礎資料と して，本報の提案指標が有用と考えている。

なお，補足しておくと，鉄筋コンクリートが存在することによっ て，RFID タグ・センサだけではなく RW にも影響が生じる。例え ば, 図 10 の例では, IC タグを RFID-C に変更しても同じょうに不 安定な通信となる。すなわち, RFID システムの選定は, 単に RF 通信機器を選び，RW を選ぶのでは不十分であり，それらの組み合 わせとしてのシステム全体で評価する必要がある。本報で示した指 標はこのような必要条件を満たしている。
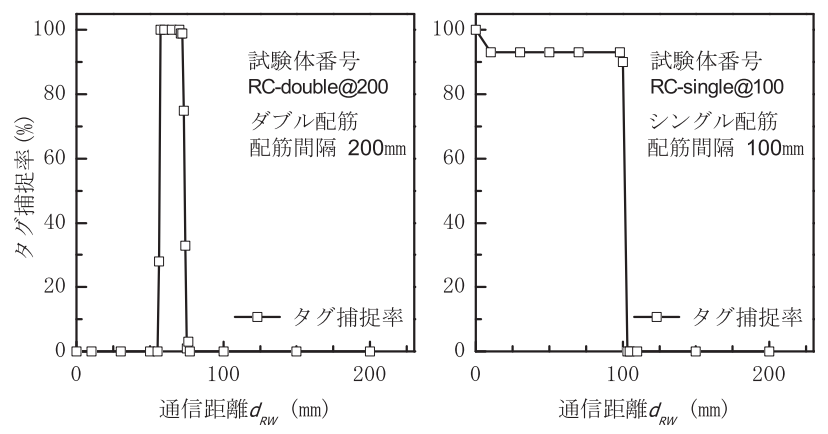

図 10 通信の安定性が無い場合の例（RC 試験体の場合） 測定条件：RW-A, RFID-A，格子中心（表 1 参照)

\section{5. 実験結果と考察 2（RC 部材に埋設する場合の通信性能評価）}

\section{1 コンクリートや鉄筋の存在がもたらす影響}

図 11 にコンクリートが存在する場合と障害物なしの場合の通信 成功率の比較を示す。また, 図 12 に鉄筋が存在する場合と障害物 なしの場合の比較を示す。いずれの水準においても，コンクリート や鉄筋が存在すると通信成功率は低下寸る傾向にあった。鉄筋の場 合の方がコンクリートより通信成功率の低下が大きかった。これは, 金属の存在の影響を受けや寸い 27) という $\mathrm{HF}$ 帯 $\mathrm{RF}$ 通信の特徵と整
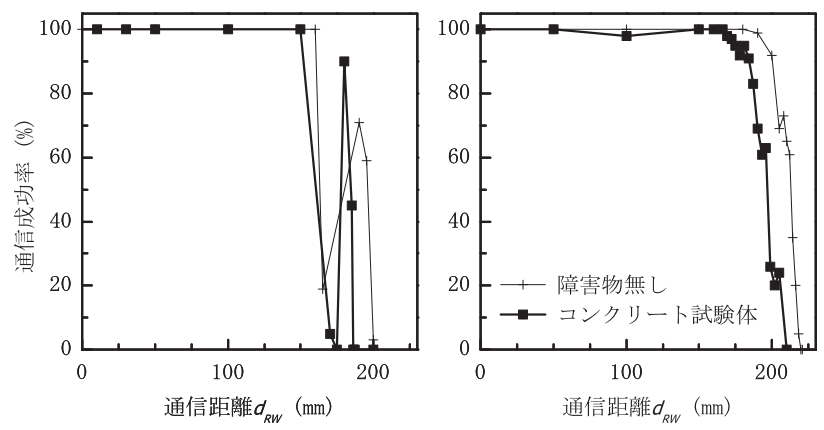

図 11 コンクリートの存在が通信成功率に及ぼす影響 測定条件（左：RW-A, RFID-B 右：RW-B, RFID-C)
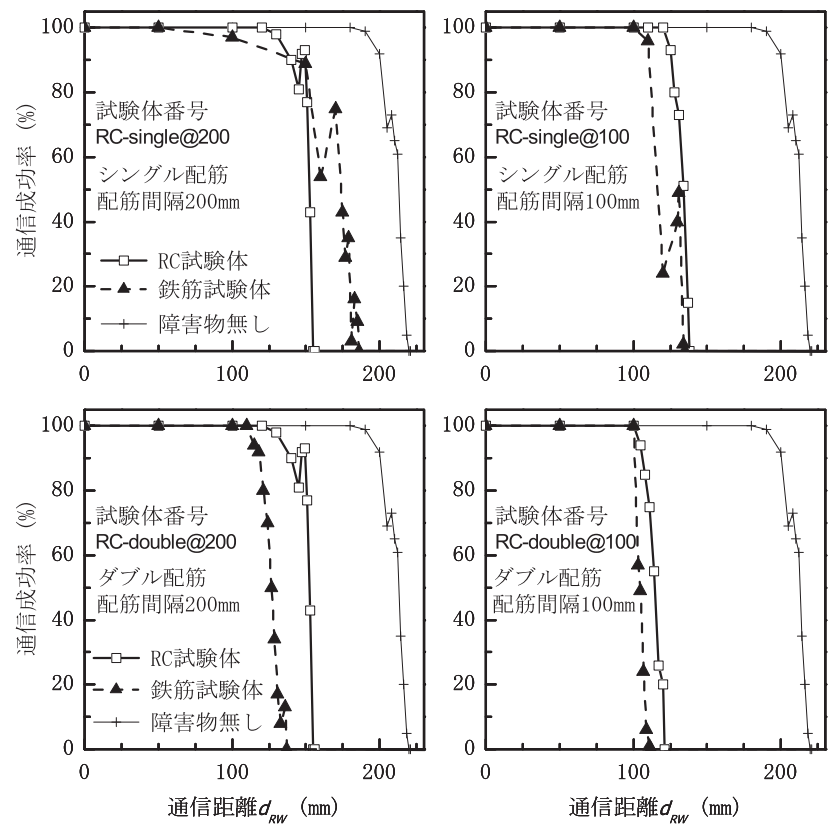

図 12 コンクリートの打設前後を想定した通信成功率の比較 （RC 試験体，測定条件：RW-B, RFID-C，格子中心，表 1 参照）

合する。なお，結果を割愛したが，タグ捕捉率についても同様に， コンクリートや鉄筋の存在によって低下寸る傾向を確認した。

\section{2 コンクリートの打設前に通信性能を予め確認できる可能性}

5.1 節では，RW と RFID タグ・センサ間にコンクリートや鉄筋 が単体で存在する場合，いずれの材料でも通信性能が低下すること を示した。この結果から単純に推論すると，鉄筋とコンクリートで 構成される鉄筋コンクリート内に RFID タグ・センサを埋設した場 合には，どちらか一方の材料しか存在しない場合よりも通信性能が 低下寸ると予想される。図 12 に RC 試験体と鉄筋試験体の同一位 置における通信成功率の比較を示す。同一の通信距離 $d_{R W}$ における 通信成功率 $R_{\text {all }}$ は, 鉄筋試験体の場合よりも $\mathrm{RC}$ 試験体のほうが高 かった。図 14 に鉄筋との相対位置を変えた場合, 眓 15 に RWを 変えた場合の測定結果を示す。これらの水準でも通信成功率 $R_{\text {all }}$ は $\mathrm{RC}$ 試験体の方が高い傾向が読み取れる。同様に，大半の試験水準 で $\mathrm{RC}$ 試験体の方が鉄筋試験体の同位置と比べて通信成功率が高い （もしくはほぼ同一）傾向を示した。

以上の結果から， RC 部材内に埋設した場合のほうが打設前の型 枠内の同位置よりも高い通信性能を確保できる場合があると示唆さ れる。また，上述の推論に反して，鉄筋やコンクリートの存在に起 因する通信性能の低下効果は加法的でないことが明らかとなった。

これらの知見は，鉄筋コンクリートに埋設する RFID タグ・セン サの通信性能予測の一つの可能性を示唆するものである。なぜなら, RFID タグ・センサを打設前の配筋の済んだ型枠内に設置して通信 が成功するのであれば，同じ位置・同機種の RWからは，コンクリ 一ト打設後にも通信可能と予測できることを意味するからである。

ただし，上記の知見（RC 部材内に埋設した場合のほうが打設前 の型枠内の同位置よりも高い通信性能を確保できる）の一般性につ いては，更なる精査の余地がある。例えば，本報で用いた RFID シ ステムは, 鉄筋やコンクリートの影響を受けにくいように配慮を施 した設計（ex. RW では Q 值 ${ }^{28)}$ を高くしすぎない，IC タグではアン 
テナに高透磁率材料を用いる 29$)$ 等）となっており，このような配 慮が無い（あるいは, さらに配慮された）システムには適用できな い知見かもしれない。また, 本報では RC 壁やスラブ部材を想定し,

(3.1 節参照), これらの部材のコンクリート打放し表面を RW で走查 することを想定したが，仕上げなどが存在すれば RW をコンクリー トから距離をとって通信することになる。このような通信距離と埋 設深さの異なる場合についても未検討である。以上のように，本節 の知見は, 現時点では, 特定の RFID システムについて，特定の $\mathrm{RC}$ 部材設計条件, 測定条件の場合にのみ再現性を確認しており, 今後，適用範囲について更なる検討が必要である。

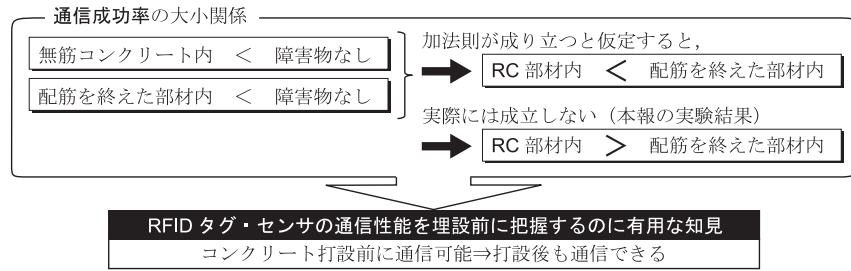

図 13 本節における推論のまとめ
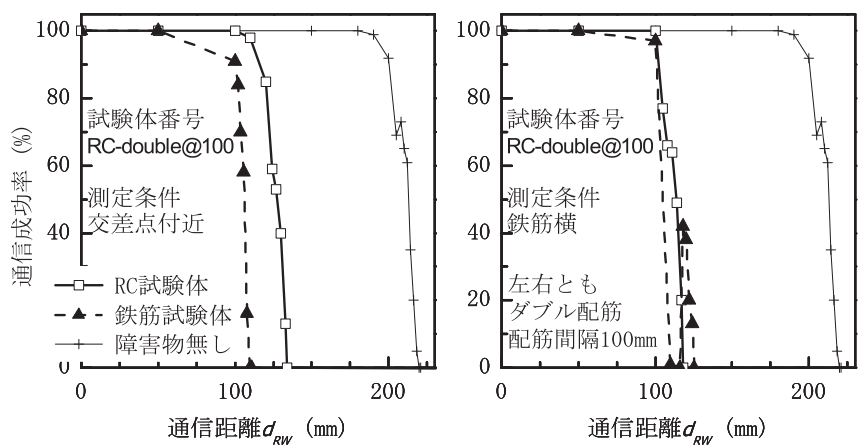

図 14 コンクリートの打設前後を想定した通信成功率の比較 （RC 試験体，測定条件：RW-B, RFID-C，表 1 参照）

鉄筋との相対位置を変えた場合（左 : 交差点付近，右：鉄筋横）
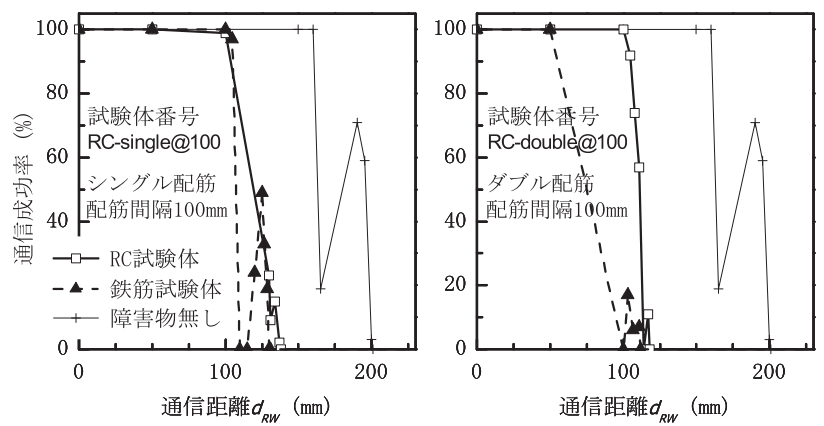

図 15 コンクリートの打設前後を想定した通信成功率の比較

（RC 試験体，測定条件：RFID-C，格子中心，表 1参照） $\mathrm{RW}$ を変えた場合（左右いずれも RW-A）

\section{6. 現象の再現性および要因分析}

5 章では, RFID タグ・センサを RC 部材内に埋設する場合, コ ンクリート打設前に通信可能であれば打設後にも通信可能, と示唆 する結果を得た。“金属が近傍に存在すると通信距離は低下する 14),27)”という既報の知見を考慮すると，上述の結果はコンクリート の存在によって，鉄筋の影響が緩和されている可能性を示唆するも のである。しかしながら，多くの実験水準で同様の傾向を示したと
はいえ，この結果は直観に反するようにも思われる。そこで本章で は， $\mathrm{RF}$ 通信の原理にもとづく必要条件を実験的に比較することに よって, 現象の再現性を検証した。

\section{6. $1 \mathrm{RF}$ 通信が成立するための必要条件と本章の考え方}

図 16 に RF 通信の原理とそれぞれの段階に対応寸る通信成立の ための必要条件を示す。最も基本的な条件の一つは, RC 部材内に 埋設された RFID タグ・センサへ必要な電力が供給されることであ る。パッシブ RFID ではアンテナ間の電磁誘導を通じて行われる。 したがって, 必要な電力供給が可能かを RFID タグ・センサが設置 されている位置における磁界強度30)を指標として評価できる。

本章では, 5 章の現象（RC 部材中の方がコンクリート打設前の同 位置よりも通信性能が高い）の主要因は, “鉄筋やコンクリートの存 在によって生じる RFID タグ・センサへの電力供給の違いにある” との仮説のもとに, 各試験水準における磁界強度の比較を行った。

\section{2 磁界強度測定の方法}

図 17 に磁界強度の測定方法の概要を示寸。図 5 の RFID タグ・ センサの設置位置を近磁界プローブで置き換え, 各試験水準の磁界 強度を測定した。磁界強度は，ハンドヘルド形の近磁界プローブを デジタルオシロスコープに接続し, 磁界センサとして用いて測定し た。近磁界プローブの出力電圧值(peek-to-peek 值) と ISO10373 の方法による磁界強度値 $(\mathrm{A} / \mathrm{m})$ を線形回帰して $(\mathrm{R} 2=0.99)$, 磁界強度 の算定に用いた。(図 18 参照)

磁界強度測定は RC 造建築物の室内で行った。ノイズ等の外部環 境によって違いが生じないことを確認するために, “障害物なし”の 水準については, 鉄骨造建築物室内, 周囲 $10 \mathrm{~m}$ に物がない屋外でも 測定し, 測定值がほぼ同一となることを確認した。R/W-C(フル充電) の磁界強度測定結果を $\mathrm{x}$ 軸を $1 /\left(d_{R W}\right)^{3}$, $\mathrm{y}$ 軸を磁界強度とし, $d_{R W} \geq 200 \mathrm{~mm}$ についてプロットして図 19 に示す。高い線形相関 (R2=0.99)が観察された。この結果は, 理論上, $d_{R W}>r_{R W}$ (ただし, $r_{R W}$ は RW の直径) の場合に, ループアンテナの磁界強度が距離 の 逆数の三乗と比例する ${ }^{32}$ ことと整合する。以上の検討によって, 本 報の測定結果が理論と整合していることを確認した。

RF 通信の原理 ${ }^{31)}$

通信の成立に必要な条件

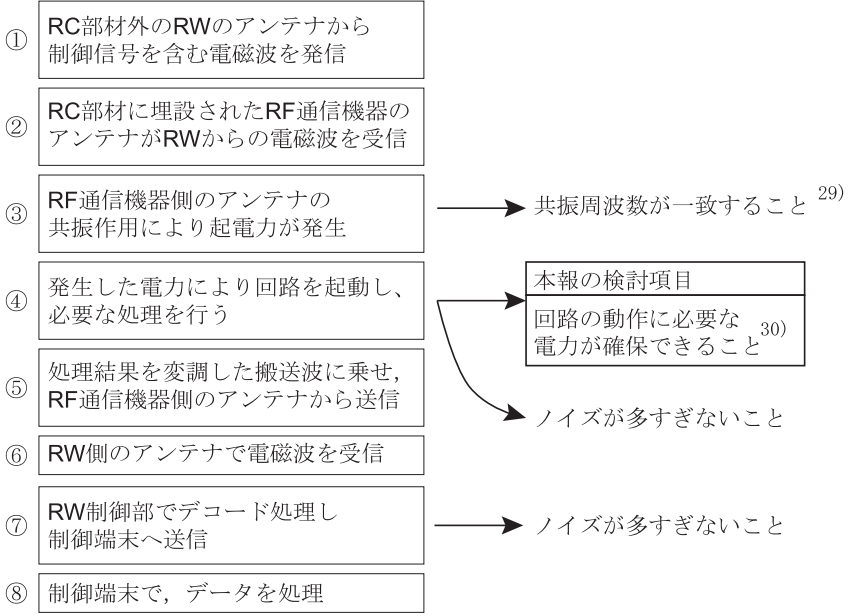

図 $16 \mathrm{RF}$ 通信の原理 31 ) と通信が成立するための必要条件 29),30) 


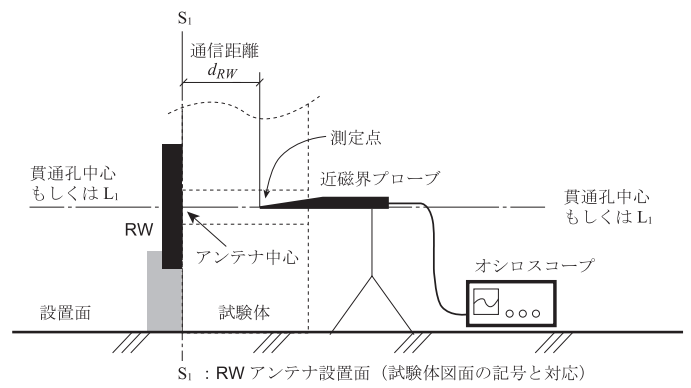

図 17 磁界強度の測定方法の概要

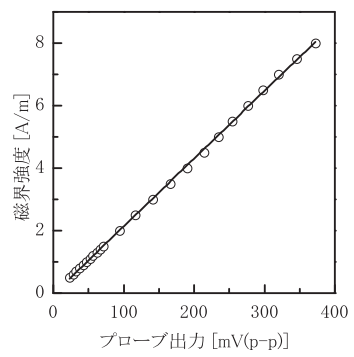

図18 近磁界プローブの出力と磁界強度の関係

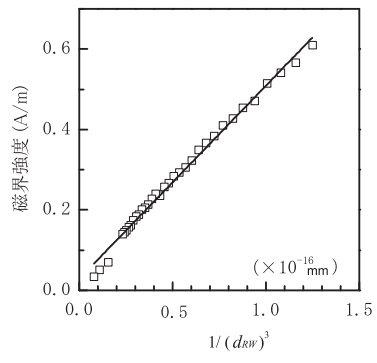

図 19 本報における磁界強度の測定值と理論 25)の整合性

（測定条件：RW-C，障害物なし）

\section{3 磁界強度測定の結果と考察（5 章の結果の再現性について）}

図 20 に, 同一位置に RFID タグ・センサがある場合を想定した 鉄筋試験体と $\mathrm{RC}$ 試験体における磁界強度を示す。配筋状態にかか わらず多くの試験水準で, $\mathrm{RC}$ 試験体内の磁界強度が鉄筋試験体の 同位置よりも磁界強度が高い傾向を示した。

図 21 に RW が異なる場合の磁界強度を同様に示す。 $\mathrm{RW}$ が変わ っても RC 試験体内の磁界強度が鉄筋試験体を上回った。図 22 に 鉄筋との相対位置が異なる場合の磁界強度を同様に示す。示さなか った試験水準を含めて, 大半の水準で $\mathrm{RC}$ 試験体内の磁界強度が鉄 筋試験体を上回った。“RC-double@100, 鉄筋横” 水準（図 22 右） が唯一， RC 試験体内の磁界強度が鉄筋試験体を下回った。図 16 に示寸他の要因が影響しているものと思われるが，今後の更なる検 討が必要である。以上の測定結果から, 通信距離や配筋の状態や鉄 筋との相対位置に関わらず， $\mathrm{RC}$ 部材内の磁界強度はコンクリート 打設前の同じ位置における磁界強度を上回ることを確認した。すな わち, RFID タグ・センサへの電力供給の点で, RC 部材内への埋設 後の方が配筋直後よりも有利となる。 $\mathrm{RF}$ 通信の原理を考慮すると, このような電力供給の差によって, 通信性能に差が生じるのは自然 な帰結であり，本結果は 5 章の結果の妥当性を示すものといえる。

以上の通信原理に基づく実験的検討を通じて，5章の結果が $\mathrm{RW}$ や $\mathrm{RC}$ 部材内の設置位置, 配筋状態などに関わらずに再現性をもつ
ことを確認した。すなわち, 本報の試験条件の範囲では, 「RC 部材 内のある位置に RFID タグ・センサを埋設する場合, ある位置の RW からコンクリート打設前に読み取り可能であれば，打設後にも通信 可能」であるものと判断される。

ただし、磁界強度の差の大きさと通信成功率の差の大きさは、必 ずしも相関が高くないように定性的に読み取れる。例えば、ダブル 配筋(double@200mm)をみると、RC 試験体と鉄筋試験体の磁界強 度の差は小さいが、通信成功率(図 12 参照)の差が比較的大きいこ とと一致していない。このような傾向は、ノイズや detune などの 他の要因(図 16 参照)による影響も無視できないことを示唆して いる。今後これらの要因についても検討することで、鉄筋やコンク リートの影響を受けにくくする技術開発の基礎資料となると考えて いる。
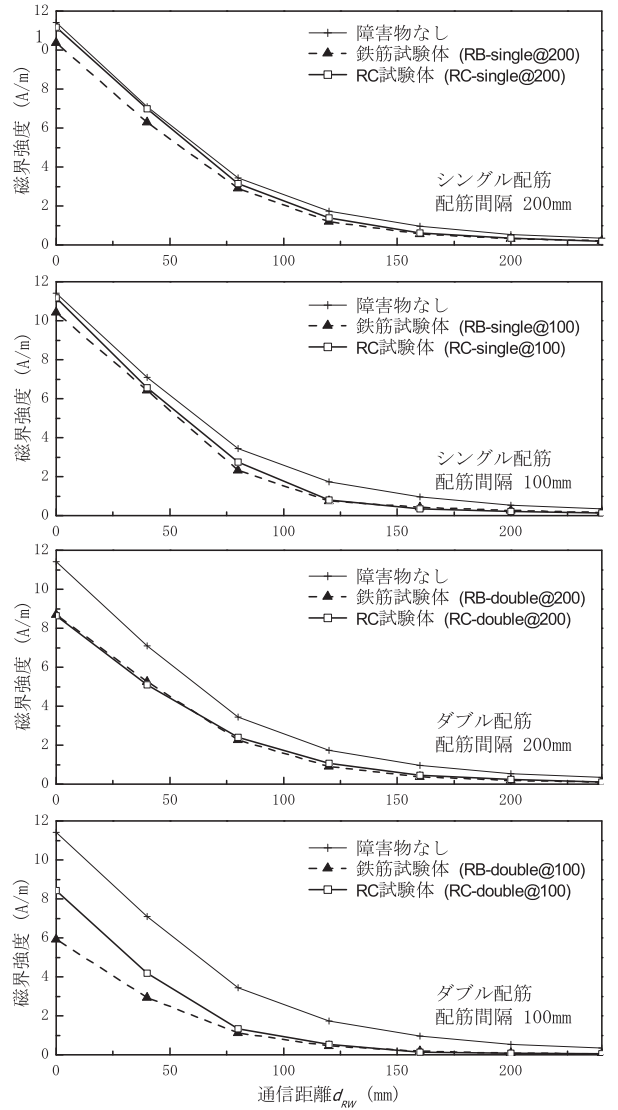

図 20 コンクリート打設前後を想定した磁界強度の比較 （測定条件：RW-B，格子中心，表 1 参照）
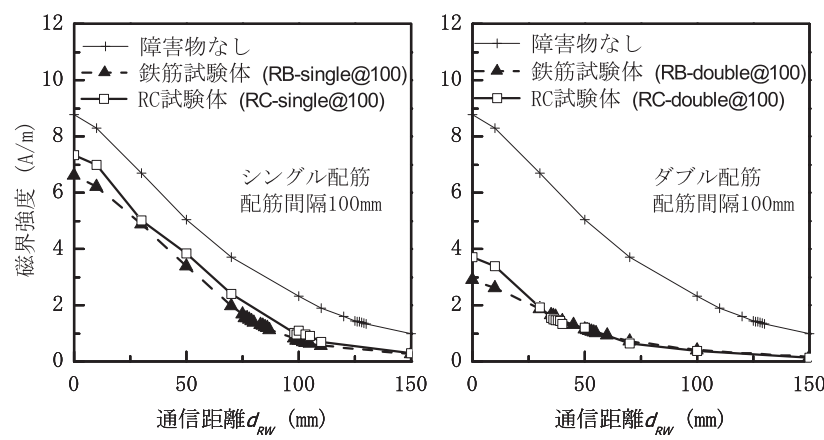

図 21 コンクリート打設前後を想定した磁界強度の比較 RW を変えた場合（測定条件：RW-A，格子中心，表 1 参照） 

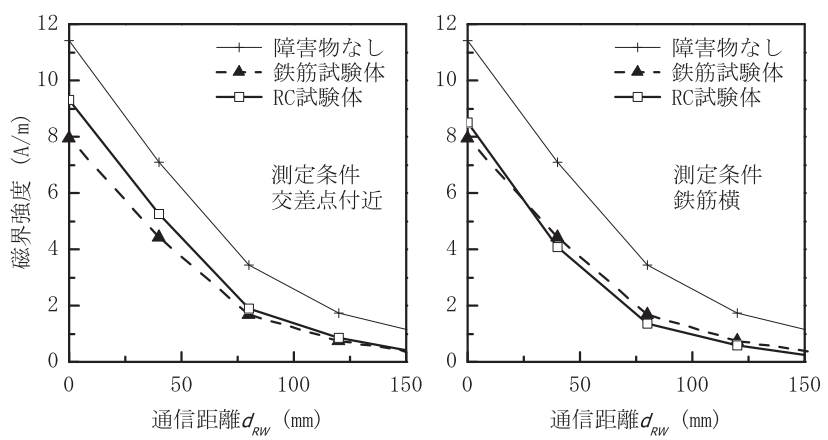

図 22 コンクリートの打設前後を想定した磁界強度の比較 鉄筋との相対位置を変えた場合（左 : 交差点付近，右 : 鉄筋横) (測定条件 : RW-B, double@100, 表 1参照)

\section{7. まとめ}

本報の成果は以下のようにまとめられる。

1） RC 部材に RFID タグ・センサ(IC タグや無線センサ) を埋 設した場合には通信性能の低下が予想される。そこで，鉄筋 やコンクリートの存在がもたらす影響を評価する観点から， $\mathrm{RF}$ 通信の手順に基づく定量的で簡便な通信性能評価指標を 提示した。

2） RC 壁・スラブ部材を模擬した各種試験体を対象に $\mathrm{RF}$ 通信 実験を行い，上述 1)で提示した指標の有用性を検証した。そ の結果, 埋設した場合の RFID タグ・センサの発見性能とデ 一夕読み書き性能に大きな違いがあることを示した。また， 通信可能距離を指標と寸る従来の方法では評価の困難な通 信安定性なども評価可能であることを示した。これらの検討 を通じて，提案指標が $\mathrm{RC}$ 部材内に埋設された場合の $\mathrm{RF}$ 通 信性能評価に適することを示した。

3）上述 2)の試験体を対象に, 鉄筋やコンクリートの存在が通信 性能に及ぼす影響を，提案指標を用いて定量的に評価した。 また, 評価を通じて, 提案指標が $\mathrm{RC}$ 部材へ適用可能である ことを示した。実験の結果から，鉄筋とコンクリートが通信 性能に与える影響には必ずしも加法性がないことを明らか にした。また, RFID タグ・センサが RC 部材内にある場合 の方が，打設前の配筋のみ行った状態の同位置よりも通信性 能が高い場合があることを示した。

ただし，この知見は，特定の RFID システム(RW3 機種, IC タグ 3 種）と特定の $\mathrm{RC}$ 部材の設計条件, 測定条件の実験的 結果に基づいており, 現時点では, これらの条件でのみ再現 性を確認している。したがって, この知見の一般性, 適用範 囲については今後, 更なる精査の必要がある。

4）上述 3)の現象の再現性を $\mathrm{RF}$ 通信の原理に基づいて, 実験的 に検証した。すなわち， RC 部材内部よりも鉄筋のみの場合 のほうが磁界強度が高いことを実験的に示し，RF 通信成立 の必要条件の大小関係から, 上述 3)の現象を合理的に説明で きることを示した。

\section{1 今後の検討課題}

$\mathrm{RC}$ 部材には様々な材料がさまざまな施工方法で利用されている。 本報はこれらを網羅しているものではない。導入部に述べたとおり、 今後, RFID 技術を導入する場合には、これらの多様な因子 (ex. コ
ンクリートの使用材料・調合・含水率・材齢、鉄筋との相対位置, 配筋の方法、部材の種別、保管の必要なデータ量 etc.) の影響を一 つ一つ，供用に先立って評価しておく必要があると考える。本報で 示した指標は、 $\mathrm{RF}$ 通信の手順に基づいているため、これらの因子 の影響を統一的に評価するための基礎資料として有用と考えている。 本報では, 複数の RW や IC タグを用いて, 再現性を確認したが, 上述の各種の要因との複合的な影響も考えられる。特に, まとめ 3 に示した通信性能のコンクリート打設前の確認方法については実 験・解析の両面から，更なる精査が必要と考えている。また，本報 では, 図 16 に示した必要条件のうち, 電力供給以外については検 討しなかった。これらの因子の影響についても検討が必要である。

\section{2 本研究の位置づけと今後の展開}

RFID タグ・センサの RC 部材への埋設は，チャレンジングな課 題であり，多くの社会的・技術的八ードルがある。一方で，建設業 自体が縮小傾向にあるなかで, 膨大な建築ストックの更新・維持管 理に高精度化・効率化が求められるのは当然のことであり，電子情 報技術はこのようなニーズに応える一つの可能性を秘めている。し たがって，まずは，電子情報技術を適正に活用するための一つ一つ の社会的・技術的な検証が重要であろうと考える。本報は，このよ うな観点から「無線通信技術」という一要素技術について検討した。 このような要素技術の検証を積み重衫ることで，効率的で信頼性の 確保された建築物の施工や維持管理モニタリングの仕組みづくりに つながると考える。

\section{謝辞}

本研究には, 日本学術振興会 科学研究費補助金 基盤研究(B)（課 題番号：22360227，H22-24）の一部を用いた。IC タグの設計，作 製および測定装置の提供など多方面にわたって関係各位のご教示と ご協力をいただいた。実験の実施には, 広島大学工学部（建築学課 程）学部学生（当時）の高橋和也君，小宮奏恵さんにご協力いただ いた。ここに記して，感謝申し上げる次第である。

\section{参考文献}

1）国土交通省 総合政策局 情報政策課建設統計室 ストック統計係：建築 物ストック統計 (平成 23 年 1 月 1 日現在)について, http://www.mlit.go.jp/ report/press/joho04_hh_000255.html, (2012.03.12 参照)

2）内閣府政策統括官 編：日本の社会資本 2007, 国立印刷局, 2007.03

3）藤本郷史：工事写真における編集痕跡検出技術の要件分析および要件に 適合した塗り潰し編集検出技術の開発と検証，日本建築学会構造系論文集， Vol.77, No.674,pp.647-656, 2012.04

4）大久保孝昭，藤本郷史，吉峰侑吾，杉山央，角倉英明，古賀順子：コンクリ ートのトレーサビリティ確保のための IC タグの活用技術 一製造時に投 入するタグの評価一, 日本建築学会技術報告集, Vol. 18, No.38, pp.31-36, 2012.02

5）藤本郷史，野口貴文，生コンクリート製造における消費電力量の定量化手 法および時間依存特性を利用した省エネルギーポテンシャルの推計, 日本 建築学会構造系論文集, Vol.76, No.665, pp.1221-1228, 2011.07

6) 蔡成浩, 土橋稔美,吉田知洋: 建築工事における建設機械の接触災害の防止 に関する研究--無線 IC タグデータに基づく作業者と建設機械の接近状態の 推定方法の検討，日本建築学会計画系論文集，Vol.75, No.656, pp.2451-2458, 2010.10

7）中島 史郎,中川 貴文,根本 かおり,古賀 純子 : RFID を活用した建物履歴 情報管理手法の開発：システムの概要と改修工事における適用事例，日本 建築学会技術報告集, Vol. 14, No.27, pp.17-20, 2008.06

8）依田浩敏：廃棄物の不法投棄・不適正処理防止のための支援システムの構 築とその実証研究，日本建築学会技術報告集, No.23, pp.229-232, 2006.6 
9) P.M. Goodrum, M.A. McLaren, A. Durfee: The application of active radio frequency identification technology for tool tracking on construction job sites, Automation in Construction, Vol. 15, Issue 3, pp.292-302, 2006

10) C.T. Tzeng, Y.C. Chiang, C.M. Chiang, C.M. Lai: Combination of radio frequency identification (RFID) verification tests of interior decorating materials, Automation in Construction, Vol.18, Issue 1, pp.16-23, 2008

11）国土交通省 国土技術政策総合研究所 : 共同研究による産学との連携状況, http://www.nilim.go.jp/lab/bbg/kyoudou/renkei/renkei21.htm （参照 : 2011.02.10)

12）小川彰一, 江里口玲, 佐藤 達三 : センサ機能付き IC タグのコンクリー トへの適用，セメントコンクリート, No.749, pp.44-50, 2009.07

13) S.Y.L. Yin, H.P. Tserng, J.C. Wang, S.C. Tsai: Developing a precast production management system using RFID next term technology, Automation in Construction, Vol.18, Issue 5, pp.677-691, 2009.08

14）杉山央, 大久保孝昭, 中島史郎：コンクリート中に埋め込んだ各種 IC タ グの通信性に関する研究，日本建築学会技術報告集，Vol.15，No.29， pp.9-14, 2009.02

15) V. Chawla, D.S. Ha: An overview of passive RFID, Communications Magazine, IEEE, Vol.45, Issue.9, pp.11-17, 2007.09

16）（社）日本自動認識システム協会：統計調査委員会活動報告, http:// www.jaisa.jp/action/committee/toukei/index.html, (参照:2011.05.26)

17）杉山央, 角倉英明, 大久保孝昭, 古賀純子, 平出務 : 大型コンクリート試 験体に埋め込んだ各種 IC タグの通信性に関する研究, 日本建築学会技術報 告集, Vol.17, No.35, pp.5-10, 2011.02

18) W. Aerts, E.D. Mulder, B. Preneel, G.A.E Vandenbosch: Dependence of RFID Reader Antenna Design on Readout Distance, IEEE Transaction of Antennas and Propagation, Vol.56.,No.12, pp.3829 - 3837, 2008.12

19) 平田勝弘, 濱本健太郎, 光武義雄, 山名正人, 大田智浩 : 電磁誘導方式に よる RFID システムの伝送特性解析に関する研究, 日本 AEM 学会誌, Vol.17, No.4, pp46-51, 2009

20）遠山徳宏, 二ッ森俊一, 日景隆, 野島俊雄, 小池勉, 藤本裕 : HF 帯 RFID リーダライタ近傍界における植込み型医用機器干涉の FDTD 解析 : 実機 特性評価による妥当性確認, 電子情報通信学会技術研究報告. EMCJ, 環境 電磁工学 Vol.108,No.97, pp.1-6, 2008.06

21) A.Cai, X.M.Qing, Z.N.Chen: High frequency RFID smart table antenna, Microwave and Optical Technology Letters, Vol.49, Issue 9, pp.2074-2076, 2007.09

22) D.H. Vo, J.-W. Lee: Analysis and design of a low power regulator for a fully integrated HF-band passive RFID tag IC, Analog Integrated Circuits and Signal Processing, Vol. 71, No.1, pp.69-80, 2012

23) L. Jongyoung, K.Naesoo: Performance Test Tool for RFID Middleware: Parameters, Design, Implementation, and Features, Proc. of Advanced Communication Technology, 2006. ICACT 2006. The 8th International Conference, pp.149-152, 2006.02

24) C. Angerer, R.Langwieser: Flexible Evaluation of RFID System Parameters using Rapid Prototyping, Proc. of the 3rd IEEE international conference on RFID, pp.42-47, 2009.04

25）大久保孝昭，藤本郷史，吉峰侑吾，杉山央，角倉英明，古賀順子：コンク リートのトレーサビリティ確保のための IC タグの活用技術 一製造時に 投入するタグの評価一, 日本建築学会技術報告集, Vol.18, No.38, pp.31-36, 2012.02

26）嶋田善多, 矢吹信喜, 坂田 智己: 土木設備の維持管理体系における巡視 点検と IC タグの活用，土木学会論文集, Vol.777, pp161-173, 2004.12

27) X.Qing, Z.N.Chen: Proximity effect of Metallic Environment on high frequency RFID reader antenna: study and application, IEEE transaction on antennas and propagation, Vol.55, No.11, pp3105-3111, 2007

28）例えば，TAKAYA 技術資料 基板選定ガイド TDR-OTH-DOUNYU-103, pp.11-13, http://www.takaya.co.jp/products/rfid/pdf/technic/TDR-OTHDOUNYU-103.pdf (2011.04.06 参照)

29）寺浦信之 監修, 遠藤貴紀 (第 11 章)： RF タグの開発技術, pp.120-129, シーエムシー出版, 2007

30) Klaus Finkenzeller 著，ソフト工学研究所訳 : RFID ハンドブック 第 2 版 非接触 IC カードの原理と応用, pp.69-75, 日刊工業新聞社, 2004.5

31) マイクロソフト Business : RFID 入門, http://www.microsoft.com/ japan/business/rfid/about/default.mspx, (参照 : 2012-2-17) の本文を参考 に著者らが図を作成した。

32) S.C.Q.Chen, V.Thomas: Optimization of inductive RFID technology, Proc. of the IEEE Int. Symposium on Electronics and the Environment 2001 IEEE ISEE, pp.82-87, 2001

33）平原悠生，吉峰侑吾，藤本郷史，大久保孝昭: $\mathrm{RC}$ 部材中に設置する $\mathrm{RFID}$ の開発とその評価に関する研究 その 2 RFID の通信性能評価, 2011 年度 日本建築学会中国支部研究報告集, pp13-16, 2012.03

注

注1）通信が途中で途切れる原因は様々であるが, 例えば以下のようなものが 考えられる。コマンド数が多いとその応答に要する電力が大きくなり, 結果として応答に失敗する可能性が高まる。また，信号に雑音が大きい 場合, CRC(Cyclic Redundancy Check)が合わないことによって通信が 終了寸ることになるが, CRC はある byte 数(ex. 本報で用いた RFID シ ステムでは 16 byteに対して 2 byte)ごとに行われるので，コマンド数が 多いほど（通信量が増えるほど）通信が中断される可能性が高まること になる。

注2）ISO14443 によれば, REQB コマンドの応答にはタグのユニーク ID ( PUPI)の情報が含まれる。したがって，本報で定義した「タグの捕 捉」が成功した場合, タグの発見だけではなく, どのタグを発見したか という情報も含まれる。例えば，文献 17)では，タグの ID が読み取れ たかどうかをもって通信の可否を判断しているが，これはタグ捕捉率で 評価しているのとほぼ同等と考えられる。一方で, 通信成功率による評 価結果とは異なる。

注3）これらの評価式は，定義上，実行されるコマンドを問わず算定できる。 しかし，RFID システムの通信性能を相対比較する用途に用いる場合， 当然のことであるが, 比較するシステム間で同一のコマンドを同一のデ 一夕内容で送信するように設定を揃えて評価する必要がある。

注4）本報で用いた RW のうち、RW-C はアンテナが被覆されていなかった。 このような場合、コンクリートや鉄筋と接することで電気抵抗の変化な どアンテナ特性への大きな影響が発生し、適切な評価とならない。そこ で、RW-C を用いた試験では、RW アンテナをコンクリート表面から 0.5〜 $1 \mathrm{~mm}$ 程度離して設置した。 RW-A， RW-B についてはこのような 配慮を行わなかった。

（2012年 4 月 6 日原稿受理，2012年10月29日採用決定） 